\title{
Hydroxy fatty acids in fresh snow samples from northern Japan: long-range atmospheric transport of Gram-negative bacteria by Asian winter monsoon
}

\author{
P. Tyagi ${ }^{1,2}$, S. Yamamoto $^{2, a}$, and K. Kawamura ${ }^{2}$ \\ ${ }^{1}$ Graduate School of Environmental Science, Hokkaido University, Sapporo, Japan \\ ${ }^{2}$ Institute of Low Temperature Science, Hokkaido University, Sapporo, Japan \\ anow at: Mount Fuji Research Institute, Yamanashi, Japan \\ Correspondence to: K. Kawamura (kawamura@lowtem.hokudai.ac.jp)
}

Received: 29 July 2015 - Published in Biogeosciences Discuss.: 19 August 2015

Revised: 27 November 2015 - Accepted: 27 November 2015 - Published: 8 December 2015

\begin{abstract}
Hydroxy fatty acids (FAs) in fresh snow from Sapporo, one of the heaviest snowfall regions in the world, have been studied to ascertain the airborne bacterial endotoxin concentrations and their biomass. The presence of $\beta$-hydroxy FAs $\left(\mathrm{C}_{9}-\mathrm{C}_{28}\right)$, constituents of the Gram-negative bacterium (GNB), suggests long-range transport of soil microbes. Likewise, the occurrence of $\alpha$ - and $\omega$-hydroxy FAs $\left(\mathrm{C}_{9}-\mathrm{C}_{30}\right.$ and $\mathrm{C}_{9}-\mathrm{C}_{28}$, respectively) in snow reveals their contribution from epicuticular waxes and soil microorganisms. Estimated endotoxin and GNB mass can aid in assessing their possible impacts on the diversity and functioning of aquatic and terrestrial ecosystems, as well as lethal effects on pedestrians through dispersal of microbes. Air mass back trajectories together with hydroxy FAs reveal their sources from Siberia, the Russian Far East and northern China by the Asian monsoon. This study highlights the role of fresh snow that reduces the human health risk of GNB and endotoxin by the scavenging from air.
\end{abstract}

\section{Introduction}

Lipid biomarkers from terrigenous plants, algae, fungi and soil microorganisms have been reported extensively in aerosols (Conte and Weber, 2002; Gagosian et al., 1987, 1981; Kawamura, 1995; Kawamura et al., 2003; Simoneit, 1977; Simoneit et al., 2004), sediments (Kawamura, 1995; Kawamura and Ishiwatari, 1984; Kawamura et al., 1987; Zhang et al., 2014), ice cores (Sankelo et al., 2013) and rain/snow (Kawamura and Kaplan, 1986; Satsumabayashi et al., 2001; Yamamoto et al., 2011). These studies have utilized fatty acids as a proxy to assess the terrigenous contribution of higher plant waxes to various environmental samples owing to their abundant presence in biopolymers of plants and microorganisms. Similarly, certain hydroxy fatty acids (e.g., $\mathrm{C}_{10}-\mathrm{C}_{18} \beta$-hydroxy $\mathrm{FAs}$ ) have been proposed as a tracer to understand the airborne bacterial transport (Tyagi et al., 2015).

Among the airborne soil microbes, the Gram-negative bacterium (GNB) is one of most extensively studied bacteria and is documented in aerosols, snow and rain samples (Morris et al., 2011). Owing to considerable ground-based emissions of GNB and its ability to act as cloud condensation nuclei $(\mathrm{CCN})$, these bacteria, which are plant pathogens, can influence the regional as well as global climate through cloud-aerosol interactions (Morris et al., 2011, and references therein). In particular, GNB contains $\beta$-hydroxy FAs $\left(\mathrm{C}_{10}-\mathrm{C}_{18}\right)$ in lipopolysaccharides (LPS) as constituents of the outer cell membrane (Westphal, 1975). Moreover, the environmental toxic effects of GNB are, in part, due to the presence of $\beta$-hydroxy FAs present in LPS (endotoxin) (Larsson, 1994; Saraf et al., 1997; Spaan et al., 2008).

Apart from $\beta$-hydroxy FAs, other positional isomers such as $\alpha$-, $\omega$ - and ( $\omega$-1)-hydroxy FAs have also been documented in various environmental archives viz. aerosols (Kawamura, 1995; Tyagi et al., 2015) and sediments (Kawamura, 1995; Wakeham et al., 2003; Zhang et al., 2014). Short chain $\alpha$ hydroxy FAs $\left(\mathrm{C}_{12}-\mathrm{C}_{18}\right)$ are the constituent biopolymers of fungi (Zelles, 1997), soil bacteria (Steinberger et al., 1999; 
Zelles and Bai, 1994) and protozoa (Ratledge and Wilkinson, 1988). In contrast, long chain $\alpha$-hydroxy FAs $\left(\mathrm{C}_{16^{-}}\right.$ $\mathrm{C}_{26}$ ) are abundant in plants, microalgae and cyanobacteria (Matsumoto and Nagashima, 1984). Likewise, $\omega$ - and ( $\omega-1)$ hydroxy FAs are highly cross-linked constituents of the cell walls of algae (Blokker et al., 1999) and plant seeds, suberin and cutin in terrestrial higher plants (Molina et al., 2006). In addition, $\omega$ - and ( $\omega$-1)-hydroxy FAs are the intermediates in the oxidation of monocarboxylic acids to dicarboxylic acids in sediments and marine aerosols (Kawamura, 1995; Kawamura and Gagosian, 1990). Furthermore, specificity of hydroxylation in FAs depends on the types of microorganisms involved (Wakeham, 1999).

These tracer compounds in snow samples may be important to better understand the contribution of plant and pathogenic bacteria to regional vs. long-range atmospheric transport (Hines et al., 2003; Lee et al., 2004, 2007; Tyagi et al., 2015) as their presence in the atmosphere can affect the $\mathrm{CCN}$ and ice nuclei activity (Morris et al., 2011). To the best of our knowledge, our study is the first to report $\alpha-\beta$ - and $\omega$-hydroxy FAs in snow samples. Snow efficiently scavenges airborne particles including soil microbes and higher plant metabolites in the free boundary layer of troposphere. Since hydroxy FAs from GNB and plants are inert in nature, they do not undergo chemical modification during snow accumulation. Therefore, hydroxy FAs in fresh snow can be used as a tracer to assess the sources and transport pathways of microorganisms and plant metabolites.

In this study, we determined hydroxy FAs in fresh snow samples collected from Sapporo, Japan, to evaluate the qualitative contribution from GNB and higher plant metabolites. Our results support the hypothesis that these hydroxy FAs are important tracers to better understand the contribution of microorganisms to the organic matter in snow. More importantly, we also discuss the possible transformations of these chemical markers during long-range atmospheric transport.

\section{Experimental methods}

\subsection{Site description and sample collection}

Sapporo $\left(43.07^{\circ} \mathrm{N}, 141.36^{\circ} \mathrm{E}\right)$ is the capital of Hokkaido, whose population is 1.9 million (June 2013). Sapporo receives cold and dry air masses with heavy snowfall during the Asian winter monsoon. The average temperature of Sapporo in winter goes up to $\sim 2{ }^{\circ} \mathrm{C}$ (Yamamoto et al., 2011). Snow cover over the ground and fallen leaves of deciduous plants suppress the suspension of soil particles during winter, whereas the emissions of plant biomarkers from local vegetation are minimal. During the winter season, the Asian monsoon affects the regional climate, air quality and human health in Japan, delivering anthropogenic aerosols and dust from China and Siberia (Yamamoto et al., 2011). Several studies have examined the chemical and isotopic composi- tion of ambient aerosols in various types of air masses in Sapporo (Aggarwal and Kawamura, 2008; Pavuluri et al., 2013; Yamamoto et al., 2011) to better understand the impacts of anthropogenic and biogenic contributions from Siberia, northern China and the surrounding oceans. However, no study that focuses on the transport of microorganisms using organic markers is available from Sapporo.

In this study, eleven fresh snow samples were collected from the rooftop of the Institute of Low Temperature Science (ILTS) building, Hokkaido University in Sapporo, during intensive snowfall periods (January-March) in 2010 and 2011. The detailed description about snow collection and analytical protocol of lipid fraction analyses is similar to that described in Yamamoto et al. (2011). To avoid the contribution of any possible impurities from the dry deposition of aerosols, 1$2 \mathrm{~cm}$ of surface snow cover were removed prior to sample collection. Thereafter, snow samples were collected in a cleaned glass jar $(8 \mathrm{~L})$ by using a stainless steel shovel. In each glass jar, mercuric chloride $\left(\mathrm{HgCl}_{2}\right)$ was added before sampling to prevent microbial activity. Soon after the collection, glass jars were tightened with a Teflon-lined screw cap and stored at $-20^{\circ} \mathrm{C}$ until analysis.

\subsection{Identification and quantification of hydroxy FAs}

The analytical protocol used for assessing the atmospheric abundances of hydroxy FAs is described in Yamamoto et al. (2011). In brief, melted snow samples $(0.5-1 \mathrm{~L})$ were saponified with $1.0 \mathrm{M} \mathrm{KOH}$ in methanol at $80^{\circ} \mathrm{C}$ for $2 \mathrm{~h}$. After saponification, the neutral fraction was separated and the remaining solution was acidified with $6 \mathrm{M} \mathrm{HCl}$ to form free carboxylic acids. Furthermore, these acids were derivatized with $\mathrm{BF}_{3} /$ methanol to form their methyl esters. The hydroxy acid methyl esters were isolated on a silica gel column by eluting with methylene chloride / methanol $(95: 5)$. The hydroxy FA methyl esters were, then, derivatized to their trimethylsilyl (TMS) ethers with N,O-bis(trimethylsilyl) trifluoroacetamide (BSTFA) (SUPELCO $^{\mathrm{TM}}$ Analytical) at $70^{\circ} \mathrm{C}$ for $1 \mathrm{~h}$. After the reaction, $50 \mu \mathrm{L}$ of $\mathrm{n}$-hexane solution containing $1.43 \mathrm{ng} \mu \mathrm{L}^{-1}$ of internal standard $\left(\mathrm{C}_{13}\right.$ n-alkane/tridecane, Wako) were added to dilute the derivatives prior to GC/MS injection (Hewlett-Packard Model 6890 GC coupled to the Hewlett-Packard Model 5973 mass-selective detector, MSD). The GC was installed with a split/splitless injector and DB-5MS fused silica capillary column.

For the quantification of hydroxy FAs, the GC oven temperature was programmed from $50^{\circ} \mathrm{C}(2 \mathrm{~min})$ to $305^{\circ} \mathrm{C}$ $(15 \mathrm{~min})$ at $5^{\circ} \mathrm{C} \mathrm{min}^{-1}$. Data were acquired and processed with the Chemstation software. Structural identification and comparison of retention time of hydroxy FAs were performed using authentic TMS derivatives of $\mathrm{n}-\mathrm{C}_{12}$ and $\mathrm{n}-\mathrm{C}_{16}$ $\alpha$-hydroxy FAs, $\mathrm{n}^{-} \mathrm{C}_{12}, \mathrm{n}-\mathrm{C}_{14}, \mathrm{n}-\mathrm{C}_{15}$, and $\mathrm{n}-\mathrm{C}_{16} \beta$-hydroxy FAs and $n-C_{16}, n-C_{20}$ and $n-C_{22} \omega$-hydroxy FAs. The recoveries of authentic fatty acid standards were better than 
$92 \pm 4 \%$ with analytical error (average $4.1 \%$ ) for acidic compounds (Yamamoto et al., 2011). Laboratory blanks showed no contamination of any target compounds. The results of n-alkanes, n-alkanols and n-alkanoic acids (terrestrial biomarkers) in snow samples are reported in Yamamoto et al. (2011), which revealed a long-range atmospheric transport of terrestrial organic materials from northeastern Asia to northern Japan by the Asian winter monsoon.

\subsection{Estimation of endotoxin levels and mass loading of GNB}

Since the endotoxins from GNB contain $\beta$-hydroxy FAs from $\mathrm{C}_{10}$ to $\mathrm{C}_{18}$, previous studies attempted to quantify atmospheric abundances of endotoxins using the concentrations of ambient hydroxy FAs measured (Lee et al., 2004; Rietschel et al., 1984; Wilkinson, 1988). According to these studies, concentrations of endotoxins in snow samples can be estimated from the mathematical expression as below.

Endotoxins (LPS, $\mathrm{ng} \mathrm{kg}^{-1}$ of meltwater) $=$ $\left[\left(\Sigma \beta\right.\right.$-hydroxy FAs from $\mathrm{C}_{10}$ to $\left.\mathrm{C}_{18} ; \mathrm{nmol} \mathrm{kg}^{-1}\right)$ $\times 8000] / 4$

In the above formula, the average molecular weight of endotoxin corresponds to 8000 as reported by Mielniczuk et al. (1993). $\beta$-Hydroxy FAs in the mathematical expression are the total (LPS-bound + free) hydroxy FAs for the carbon numbers from $\mathrm{C}_{10}$ to $\mathrm{C}_{18}$. We also estimated the mass loading of airborne GNB using the approach initially suggested by Balkwill et al. (1988) and later on by Lee et al. (2004), in which they used the chemical marker to bacterial mass conversion factor of $15 \mathrm{nmol}$ of $\beta$-hydroxy FAs $\left(\mathrm{C}_{10}-\mathrm{C}_{18}\right)$ per $\mathrm{mg}$ dry cell weight. Therefore, we have converted the sum of mass concentrations of $\beta$-hydroxy FAs from $\mathrm{C}_{10}$ to $\mathrm{C}_{18}$ (in $\mathrm{nmol} \mathrm{kg}{ }^{-1}$ ) into the equivalent dry cell weight of GNB (i.e., in $\mathrm{mg} \mathrm{kg}^{-1}$ of meltwater) by normalizing with 15 .

\section{Results and discussion}

\subsection{Air mass backward-trajectory analysis}

The air mass back trajectories (AMBTs) provide a means to qualitatively assess the source regions of airborne pollutants over a receptor site. For this study, we have computed 7day isentropic AMBTs using the Hybrid Single Particle Lagrangian Integrated Trajectory (HYSPLIT) model (Draxler and Rolph, 2013, and references therein). The meteorological parameters (GDAS data sets) from the NOAA Air Resources Laboratory were used as an input for the HYSPLIT model. Figure 1 shows the AMBT cluster at an arrival height of $500 \mathrm{~m}$ over Sapporo during sampling days of the winter of 2010 and 2011. In almost all snow-sampling periods in Sapporo, the AMBTs show plausible influence of air

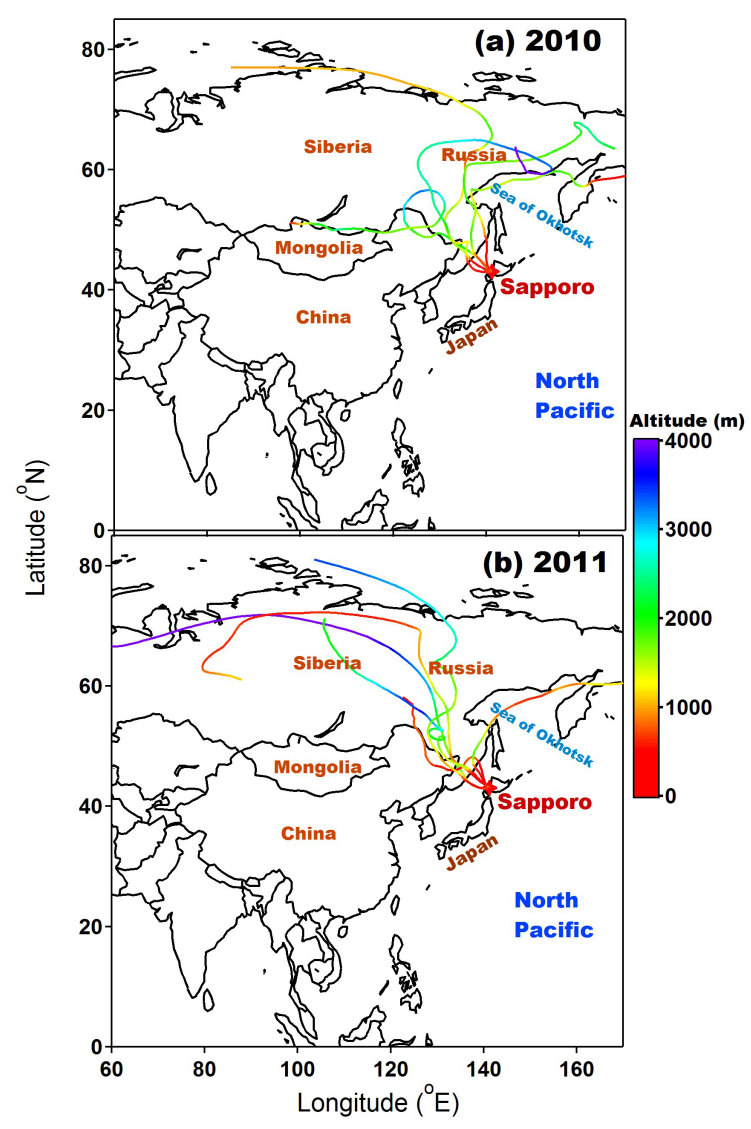

Figure 1. Air mass back-trajectory cluster at an arrival height of $500 \mathrm{~m}$ a.g.l. (above ground level) for the sampling days in (a) winter 2010 and (b) winter 2011.

masses from Russia and Siberia via the long-range atmospheric transport.

\subsection{Concentrations of hydroxy fatty acids}

Homologous series of $\alpha$-, $\beta$ - and $\omega$-hydroxy FAs were detected in fresh snow samples collected from Sapporo. Their mass concentrations are summarized in Tables 1 and 2 for the winters of 2010 and 2011, respectively. Based on 2-year seasonal data on hydroxy FAs, we found that concentrations of $\alpha$-hydroxy FAs are significantly higher than $\beta$ - and $\omega$ hydroxy FAs. The predominance of $\alpha$-hydroxy FAs can be explained by the $\alpha$-oxidation pathway of FAs, which generally occurs in plants, animals and bacteria (Cranwell, 1981, and references therein) whereas $\beta$ - and $\omega$-oxidation is specific to bacteria (Lehninger, 1975). $\alpha$-Hydroxy FAs, in particular high molecular weight ones, come from the epicuticular waxes of higher plants as well as from algae. However, we also found higher abundance of $\alpha$-hydroxy FAs in the biomass burning aerosols collected over Mt. Tai, China (Tyagi et al., 2015), possibly due to photochemical oxidation of higher molecular weight fatty acids. Such a possibility of in situ formation of $\alpha$-hydroxy FAs has also been 
Table 1. Mass concentrations (in $\mathrm{ng} \mathrm{kg}^{-1}$ ) of $\alpha$-, $\beta$ - and $\omega$-hydroxy fatty acids (FAs) measured in snow samples $(N=5)$ collected from Sapporo during the winter of 2010.

\begin{tabular}{|c|c|c|c|c|c|c|c|c|c|}
\hline \multicolumn{10}{|c|}{2010} \\
\hline \multirow[t]{2}{*}{ C-number } & \multicolumn{3}{|c|}{$\alpha$-Hydroxy FAs } & \multicolumn{3}{|c|}{$\beta$-Hydroxy FAs } & \multicolumn{3}{|c|}{$\omega$-Hydroxy FAs } \\
\hline & Range & Mean \pm S.E. & Median & Range & Mean \pm S.E. & Median & Range & Mean \pm S.E. & Median \\
\hline $\mathrm{C}_{9}$ & b.d. -7.1 & $2.4 \pm 1.3$ & 1.7 & $0.5-2.7$ & $1.8 \pm 0.47$ & 2 & b.d. -1.7 & $0.97 \pm 0.4$ & 1.4 \\
\hline $\mathrm{C}_{10}$ & b.d. -37.3 & $14.6 \pm 7.6$ & 10.9 & $1.7-6.5$ & $4.6 \pm 1.2$ & 5.1 & b.d. -5.1 & $1.7 \pm 1.1$ & 0 \\
\hline $\mathrm{C}_{11}$ & b.d. -35.1 & $21 \pm 6.5$ & 21.1 & $3.4-7.9$ & $6.1 \pm 0.8$ & 6.2 & b.d.-6.4 & $2.2 \pm 1.4$ & 0 \\
\hline $\mathrm{C}_{12}$ & b.d. -46.7 & $25.3 \pm 7.8$ & 22.6 & $8-10.1$ & $9.2 \pm 0.4$ & 9.8 & b.d. -95.6 & $47.2 \pm 17.8$ & 32.7 \\
\hline $\mathrm{C}_{13}$ & b.d. -45.2 & $20 \pm 7.3$ & 18 & $3.5-11.9$ & $7.1 \pm 1.8$ & 6 & b.d. -5.1 & $3.7 \pm 0.9$ & 4.4 \\
\hline $\mathrm{C}_{14}$ & b.d. -53.4 & $27.1 \pm 8.5$ & 27.6 & $16.6-40.9$ & $23.5 \pm 4.4$ & 19.6 & b.d. -196.7 & $101 \pm 34.7$ & 79.8 \\
\hline $\mathrm{C}_{15}$ & b.d. -44 & $18.6 \pm 7.2$ & 16.4 & $2.9-10.8$ & $6.8 \pm 1.4$ & 6.7 & b.d. -17 & $9.6 \pm 3.1$ & 12.8 \\
\hline $\mathrm{C}_{16}$ & b.d.-139 & $89.2 \pm 23.6$ & 97.8 & $21.7-79.4$ & $45.1 \pm 9.4$ & 4.4 & $2.3-754.1$ & $296 \pm 129$ & 256.3 \\
\hline $\mathrm{C}_{17}$ & b.d. -26.5 & $12.4 \pm 4.4$ & 10 & $3.1-10.7$ & $7.5 \pm 1.3$ & 8.4 & b.d.-12.6 & $7.1 \pm 2$ & 8.1 \\
\hline $\mathrm{C}_{18}$ & b.d. -44.7 & $26.2 \pm 8.1$ & 26.3 & $23.4-52.3$ & $33.5 \pm 6.6$ & 29.1 & b.d. -43.9 & $21.2 \pm 6.9$ & 21 \\
\hline $\mathrm{C}_{19}$ & b.d. -20.1 & $11.5 \pm 3.4$ & 11.5 & $5.3-21.7$ & $10.4 \pm 3.8$ & 7.3 & b.d. -12.2 & $5.5 \pm 2$ & 5.7 \\
\hline $\mathrm{C}_{20}$ & b.d. -46.6 & $25 \pm 7.8$ & 21.5 & $14.4-120$ & $48.3 \pm 25$ & 29.2 & $0.2-45.6$ & $17.2 \pm 7.6$ & 13.5 \\
\hline $\mathrm{C}_{21}$ & b.d.-21.1 & $12.1 \pm 3.7$ & 11.2 & $5.6-28.8$ & $14.8 \pm 5.4$ & 13 & b.d.-8.7 & $3.6 \pm 1.4$ & 3 \\
\hline $\mathrm{C}_{22}$ & b.d. -73.7 & $40.8 \pm 13.1$ & 37.7 & $11.2-30.4$ & $19.5 \pm 4.1$ & 18.2 & b.d. -318 & $96.4 \pm 56.5$ & 50.7 \\
\hline $\mathrm{C}_{23}$ & b.d. -32.8 & $18.5 \pm 5.8$ & 18.3 & $2.8-33.9$ & $13.2 \pm 7.1$ & 8.1 & b.d. -9.2 & $3.8 \pm 1.6$ & 3.6 \\
\hline $\mathrm{C}_{24}$ & b.d. -145 & $64 \pm 25$ & 56.8 & $6.2-29$ & $15 \pm 5.1$ & 12.3 & b.d. -72.4 & $24.1 \pm 12.7$ & 13 \\
\hline $\mathrm{C}_{25}$ & b.d. -39.1 & $18.4 \pm 6.7$ & 15.4 & $1.4-17.4$ & $7.7 \pm 3.4$ & 5.9 & b.d. -2.6 & $1.02 \pm 0.5$ & 1.2 \\
\hline $\mathrm{C}_{26}$ & b.d. -49.3 & $18.6 \pm 9$ & 15.8 & b.d.-18 & $7.5 \pm 3.8$ & 6 & b.d. -3.2 & $0.6 \pm 0.6$ & 0 \\
\hline $\mathrm{C}_{27}$ & b.d. -14.4 & $4.4 \pm 2.8$ & 1.1 & b.d. -2.7 & $0.7 \pm 0.7$ & 0 & b.d. -0.2 & $0.03 \pm 0.03$ & 0 \\
\hline $\mathrm{C}_{28}$ & b.d. -10.9 & $4 \pm 2.5$ & 0 & b.d. -1.6 & $0.3 \pm 0.3$ & 0 & & & \\
\hline $\mathrm{C}_{29}$ & b.d. -0.54 & $0.1 \pm 0.1$ & 0 & & & & & & \\
\hline $\mathrm{C}_{30}$ & b.d. -0.32 & $0.06 \pm 0.06$ & 0 & & & & & & \\
\hline Total & $432-774$ & $593 \pm 88$ & 582 & $70-379$ & $247 \pm 52$ & 252 & $2-1411$ & $643 \pm 228$ & 530 \\
\hline
\end{tabular}

reported in the hydrolysis products of leaf waxes and wood, and in microalgae and sea grasses (Feng et al., 2015). Furthermore, microbial oxidation could also be a possible source of $\alpha$-hydroxy FAs (Eglinton et al., 1968) in the snow samples studied. Hence, we suggest that $\alpha$-hydroxy FAs cannot be employed as the tracers of plant waxes only, as they can come from microbial/photochemical oxidation of higher molecular weight fatty acids during long-range atmospheric transport.

A characteristic feature of our data is the predominance of $\mathrm{C}_{16}$ hydroxy FAs in all the types of hydroxy FAs measured. However, significant shifts were observed in the carbon numbers of the second-most abundant $\beta$-hydroxy FAs (mostly Cnumber $>16$ ) and $\omega$-hydroxy FAs (i.e., $\mathrm{C}$-number $<16$; see Tables 1 and 2). A likely explanation for this observation is that $\beta$-hydroxy FAs above $\mathrm{C}_{16}$ were formed by $\beta$-oxidation of long chain FAs, which are more common in microorganisms as discussed previously. In contrast, $\omega$-hydroxy FAs below $\mathrm{C}_{16}$ are present in plants and microbes (Cardoso and Eglinton, 1983), in which $\omega$-oxidation of fatty acids is the secondary choice for microbial oxidation.

\subsection{Molecular distributions}

Figure 2 presents molecular distributions of $\alpha-\left(\mathrm{C}_{9}\right.$ to $\left.\mathrm{C}_{30}\right)$, $\beta$ - and $\omega$-hydroxy FAs $\left(\mathrm{C}_{9}\right.$ to $\left.\mathrm{C}_{28}\right)$ in snow samples from Sapporo during the winter of 2010 and 2011. Even carbon number predominance is noteworthy for $\alpha-, \beta$ - and $\omega$ hydroxy FAs. $\alpha$-Hydroxy FAs show molecular distributions with the order $\mathrm{C}_{16}>\mathrm{C}_{24}>\mathrm{C}_{22}$ in both years (see Fig. 2a). Likewise, $\beta$-hydroxy FAs show the predominance of $\mathrm{C}_{16}$ followed by $\mathrm{C}_{18}$ or $\mathrm{C}_{20}$ and then by $\mathrm{C}_{14}$ in both winters. However, we found the predominance of $\mathrm{C}_{20} \beta$-hydroxy FAs over $\mathrm{C}_{16}$ in one snow sample during 2010. Similarly, $\omega$-hydroxy FAs showed dominance of $\mathrm{C}_{16}$ followed by the others as $\mathrm{C}_{14}>\mathrm{C}_{12} \sim \mathrm{C}_{22} \sim \mathrm{C}_{24}$ during snowfall in both the years.

Table S1 in the Supplement describes the statistically significant differences in the ratios of even to odd carbon numbers for $\alpha-, \beta$-, and $\omega$-hydroxy FAs in snow samples based on a two-tailed unpaired $t$ test. No significant differences were observed between 2010 and 2011 for the ratios of even to odd carbon number $\alpha$-hydroxy FAs. In contrast, the difference is statistically significant between 2010 and 2011 for $\beta$ - and $\omega$-hydroxy FAs. In fact, the difference is much larger for $\omega$-hydroxy FAs than that for $\beta$ isomers. In the 2010 
Table 2. Mass concentrations (in $\mathrm{ng} \mathrm{kg}^{-1}$ ) of $\alpha$-, $\beta$ - and $\omega$-hydroxy fatty acids (FAs) measured in snow samples $(N=6)$ collected from Sapporo during the winter of 2011.

\begin{tabular}{|c|c|c|c|c|c|c|c|c|c|}
\hline \multicolumn{10}{|c|}{2011} \\
\hline C-number & Range & Mean \pm S.E. & Median & Range & Mean \pm S.E. & Median & Range & Mean \pm S.E. & median \\
\hline $\mathrm{C}_{9}$ & b.d.-27.2 & $14.2 \pm 5.7$ & 13.8 & $1-8.5$ & $5.1 \pm 1.3$ & 6 & b.d. -16.4 & $11.0 \pm 2.6$ & 12.9 \\
\hline $\mathrm{C}_{10}$ & b.d. -65.4 & $30.9 \pm 11.2$ & 33.3 & $1.7-12.7$ & $8.1 \pm 1.8$ & 8.8 & b.d. -4.7 & $0.8 \pm 0.8$ & 0 \\
\hline $\mathrm{C}_{11}$ & $19.8-66.6$ & $34.2 \pm 8.5$ & 28.5 & $1.7-13.3$ & $9.2 \pm 1.9$ & 10.1 & b.d. -4.7 & $0.8 \pm 0.8$ & 0 \\
\hline $\mathrm{C}_{14}$ & $7.5-55.3$ & $28.6 \pm 7.7$ & 28.4 & $4.5-25.5$ & $13.7 \pm 4$ & 16.6 & b.d. -61.5 & $17.7 \pm 9.3$ & 9.1 \\
\hline $\mathrm{C}_{15}$ & b.d.-77.6 & $29.2 \pm 13.1$ & 23.3 & $1.9-11.1$ & $6.3 \pm 1.8$ & 7.7 & b.d.-12.1 & $4.0 \pm 2.2$ & 3.9 \\
\hline $\mathrm{C}_{16}$ & $14.3-186$ & $94.0 \pm 29.3$ & 92.5 & $2.8-55.8$ & $30.5 \pm 10.2$ & 32.8 & b.d.-159 & $42.9 \pm 24.7$ & 19.4 \\
\hline $\mathrm{C}_{17}$ & $2.8-29.3$ & $15.3 \pm 4.3$ & 14.5 & $1.6-12.2$ & $7.7 \pm 2.2$ & 9 & b.d. -8.2 & $1.9 \pm 1.3$ & 0.3 \\
\hline $\mathrm{C}_{18}$ & $8.0-55.8$ & $31.3 \pm 8.2$ & 29.9 & $0.6-31.4$ & $14.4 \pm 5.3$ & 13.6 & b.d. -18.2 & $5.8 \pm 2.8$ & 3.9 \\
\hline $\mathrm{C}_{23}$ & $8.1-58.1$ & $32.2 \pm 10.1$ & 26.3 & $5.7-11.6$ & $9.1 \pm 1.7$ & 10 & b.d. -6.8 & $1.2 \pm 1.1$ & 0 \\
\hline $\mathrm{C}_{24}$ & $12.3-92.2$ & $74.9 \pm 34$ & 34 & $19.1-24.3$ & $22.2 \pm 1.6$ & 23.1 & b.d. -38 & $9.1 \pm 6.0$ & 3.2 \\
\hline $\mathrm{C}_{25}$ & $2.6-51.3$ & $18.4 \pm 8.9$ & 9.8 & $3.3-11.1$ & $8.5 \pm 2.6$ & 11.1 & b.d. -3.7 & $1.0 \pm 0.6$ & 0 \\
\hline $\mathrm{C}_{26}$ & $2.6-52.0$ & $24.2 \pm 9$ & 23.5 & b.d. -15.9 & $6.4 \pm 3.1$ & 4 & b.d. -10 & $2.2 \pm 1.6$ & 0.1 \\
\hline $\mathrm{C}_{27}$ & b.d. -5.6 & $2 \pm 1.3$ & 0 & b.d. -9.2 & $3.3 \pm 1.6$ & 2.1 & & & \\
\hline $\mathrm{C}_{28}$ & b.d. -4.8 & $1.4 \pm 0.9$ & 0 & b.d. -10.6 & $4.3 \pm 2.1$ & 2.3 & b.d.-1.4 & $0.2 \pm 0.2$ & 0 \\
\hline $\mathrm{C}_{29}$ & b.d. -3.35 & $0.7 \pm 0.67$ & 0 & & & & & & \\
\hline $\mathrm{C}_{30}$ & b.d. -0.60 & $0.12 \pm 0.12$ & 0 & & & & & & \\
\hline Total & $169-1279$ & $639 \pm 187$ & 651 & $6-354$ & $179 \pm 64$ & 170 & $27-422$ & $149 \pm 73$ & 102 \\
\hline
\end{tabular}

Note: b.d. $=$ below detection limit $\leq 0.06 \mathrm{ng} \mathrm{kg}^{-1}$. S.E. (standard error) $=\sigma / N^{1 / 2}$, where $\sigma$ refers to the standard deviation of total samples $(N)$.

winter, AMBTs show atmospheric transport from the continents at 500, 1000 and $1500 \mathrm{~m}$ above ground; however, at the same heights in the 2011 winter, the air masses came from the oceans during one sample collection. Higher plants in the continents contribute to higher abundances of hydroxy FAs than the oceans, and thus explain higher abundances of $\beta$ - and $\omega$-hydroxy FAs in 2010 than in 2011. On average, even carbon numbered $\alpha$-, $\beta$ - and $\omega$-hydroxy FAs in their total mass concentrations account for $\sim 69,68$ and $84 \%$, respectively. The even carbon number predominance is also found in recent marine and lacustrine sediments (Cardoso and Eglinton, 1983; Goossens et al., 1986; Kawamura, 1995; Zhang et al., 2014).

Similar to our study, Volkman et al. (1980) documented the bimodal distribution of $\alpha$-hydroxy FAs with peaks at $\mathrm{C}_{16}$ and $\mathrm{C}_{24}$ in the intertidal sediments from Victoria, Australia, and attributed their contribution from sea grass (i.e., Zostera muelleri) detritus owing to similar distribution patterns. However, it is noteworthy that our AMBTs show a continental origin rather than the oceanic origin. Therefore, it is possible that waxes emitted from continental grasses via wind abrasion can be transported to Sapporo through the atmosphere. We speculate that $\alpha$-hydroxy FAs $\left(\mathrm{C}_{16}-\mathrm{C}_{28}\right)$ in Sapporo snow can be used as a tracer of plant waxes. Likewise, higher plant-derived cutin and suberin have been suggested as a significant source of $\mathrm{C}_{16}$ to $\mathrm{C}_{22} \alpha-, \beta$ - and $\omega$-hydroxy FAs (Cardoso and Eglinton, 1983). In a similar way, it has been proposed that hydroxy FAs $\left(\mathrm{C}_{20}-\mathrm{C}_{30}\right)$ are principally derived from terrestrial higher plants (Kawamura and Ishiwatari, 1984). Therefore, $\alpha-, \beta$ - and $\omega$-hydroxy FAs $\left(\mathrm{C}_{16}-\mathrm{C}_{22}\right)$ in snow samples can be related to their sources from terrestrial higher plants through long-range atmospheric transport.

Previous studies documented ubiquitous occurrence of these hydroxy FAs in soil microbes such as yeast and fungi (Van Dyk et al., 1994, and references therein) and in the LPS of GNB (Lee et al., 2007). In this regard, prior studies focussing on $\beta$-hydroxy FAs with the predominance of $\mathrm{C}_{16}$ and $\mathrm{C}_{18}$ suggested the contributions from yeast and fungi (Stodola, 1967; Van Dyk et al., 1994, and references therein). Molecular distributions of $\beta$-hydroxy FAs show a predominance of $\mathrm{C}_{16}$ followed by $\mathrm{C}_{18}$ or $\mathrm{C}_{20}$ (see Fig. 2b), suggesting that they have been derived from soil microbes. Likewise, FAs $<\mathrm{C}_{20}$ are derived from marine phytoplankton (Kawa- 


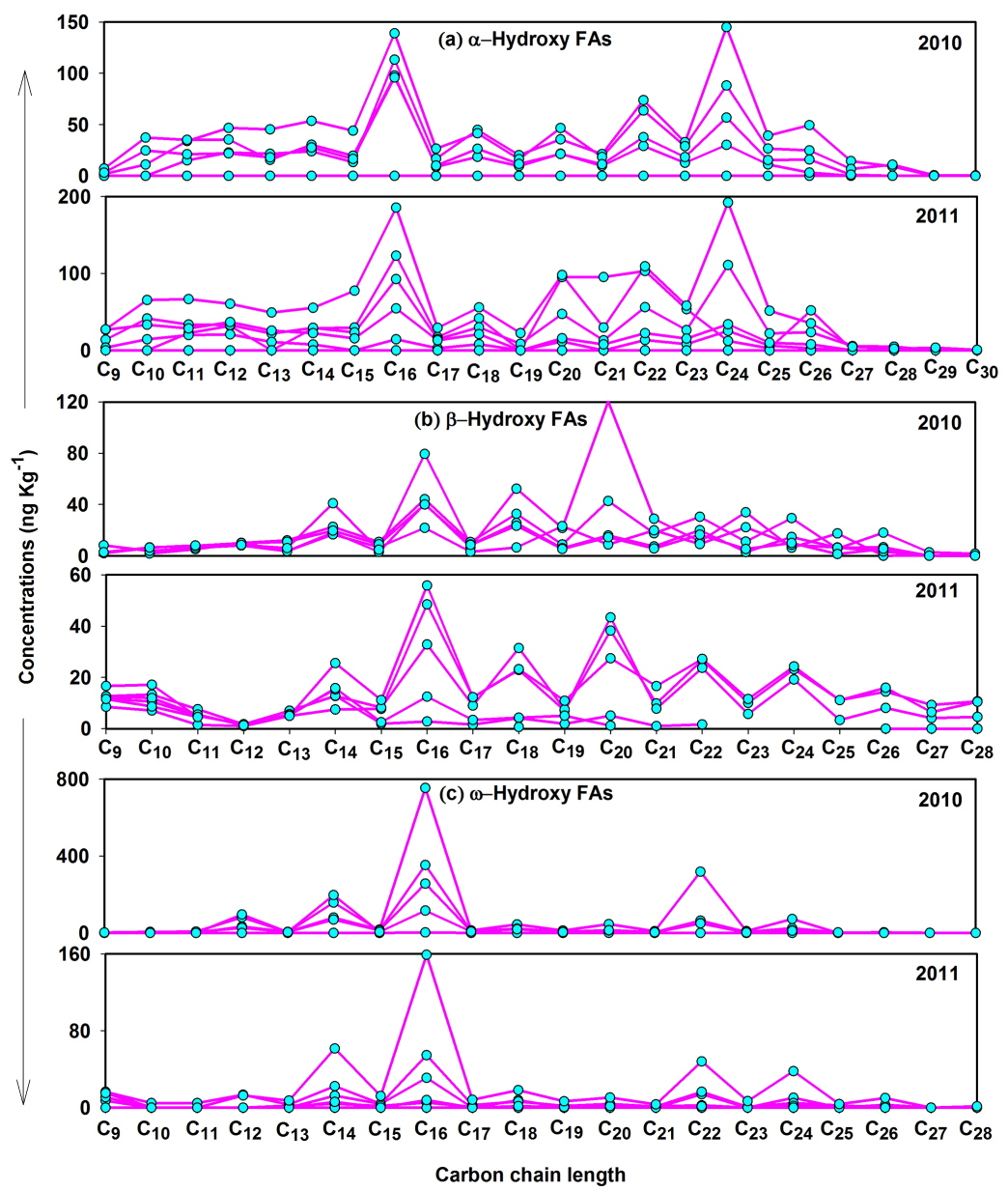

Figure 2. Molecular distributions of (a) $\alpha$-hydroxy fatty acids (FAs) $\left(\mathrm{C}_{9}-\mathrm{C}_{30}\right)$, (b) $\beta$-hydroxy FAs $\left(\mathrm{C}_{9}-\mathrm{C}_{28}\right)$ and (c) $\omega$-hydroxy $\mathrm{FAs}_{2}\left(\mathrm{C}_{9}-\right.$ $\mathrm{C}_{28}$ ) in the snow samples collected from Sapporo during the winter of 2010 and 2011.

mura, 1995, and references therein). $\beta$-Hydroxy FAs $\left(\mathrm{C}_{10^{-}}\right.$ $\mathrm{C}_{18}$ ) have been proposed as a biomarker for soil microbes as they are the constituents of LPS of GNB (Lee et al., 2004; Szponar et al., 2002). Hence, it is likely that $\beta$-hydroxy FAs in snow samples may have been significantly influenced by GNB and terrestrial higher plant metabolites.

Figure 3 depicts bar graphs showing the relative abundances of $\alpha-, \beta$ - and $\omega$-hydroxy FAs in the snow samples from Sapporo during winter. We found that the proportions of two classified groups (low molecular weight $\mathrm{C}_{9}-\mathrm{C}_{19}$ and high molecular weight $\mathrm{C}_{20}-\mathrm{C}_{30}$ or $\left.\mathrm{C}_{20}-\mathrm{C}_{28}\right)$ of $\alpha-\beta$ - and $\omega$-hydroxy FAs are very similar between 2010 and 2011 (Fig. 3). This observation is perhaps related to their common sources/transport pathways of $\alpha$-, $\beta$ - and $\omega$-hydroxy FAs over Sapporo. This inference is further supported by the AMBTs computed at arrival heights of 500, 1000 and $1500 \mathrm{~m}$ (see Figs. 1 and S1 in the Supplement), indicating similar air mass transport pathways from Russia and Siberia.

\subsection{Endotoxin potency of GNB impact via aeolian transport}

Endotoxin in GNB determines their viability and potentially causes pathological effects on mammals (Lüderitz et al., 1981; Westphal, 1975). In particular, GNB contain LPS in their outer membrane. When bacteria multiply, die and lyse, LPS are released from the surface as a potential bacterial toxin, and are therefore called an endotoxin (Westphal, 1975). In addition to intact bacterial cells, this endotoxin can trigger and cause allergies, respiratory problems and infections. Researchers have used LPS concentrations as a measure of GNB, primarily by the limulus amebocyte lysate (LAL) assay that has limited specificity (Saraf et al., 1997). The $\beta$-hydroxy FAs, markers for endotoxin/LPS, were assayed in various environmental samples such as dust (Andersson et al., 1999; Hines et al., 2000), aerosols (Lee et al., 2004, 2007; Walters et al., 1994), soils (Keinänen et al., 2003), sewage (Spaan et al., 2008) and marine dissolved organic matter (Wakeham, 1999). 


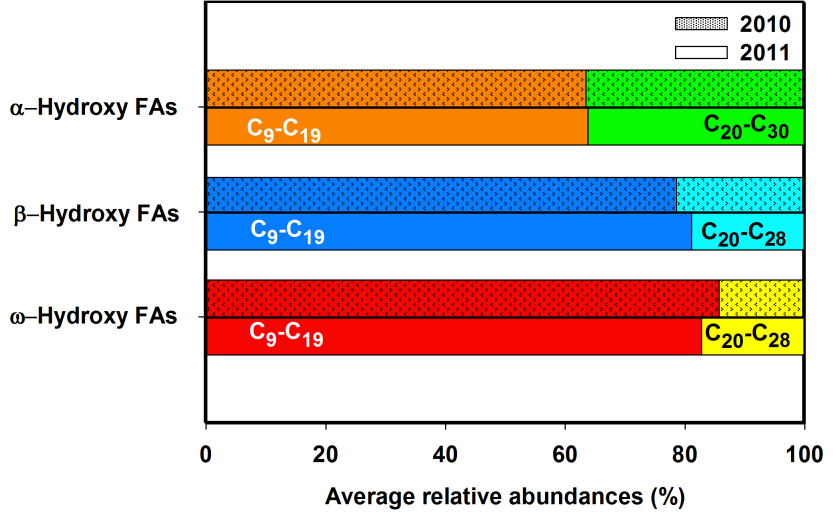

Figure 3. Bar graph, showing the relative abundances of low molecular weight $\left(\mathrm{C}_{9}-\mathrm{C}_{19}\right)$ and high molecular weight fatty acids $\left(\mathrm{C}_{20}-\right.$ $\mathrm{C}_{30}$ for $\alpha$-hydroxy; $\mathrm{C}_{20}-\mathrm{C}_{28}$ for $\beta$ - and $\omega$-hydroxy) in their total mass for the snow samples collected during the winter of 2010 and 2011. The upper and lower horizontal bars for each type of hydroxy fatty acid indicate the data for 2010 and 2011, respectively.

As mentioned in Sect. 2.3, we have estimated the abundances of endotoxin and mass loading of GNB in fresh snow samples. This quantification is indeed crucial for assessing a likely allergic impact of endotoxin globally via long-range atmospheric transport. Here, we estimated the endotoxin concentrations in snow as varying from 424 to $1080 \mathrm{ng} \mathrm{kg}^{-1}$ (ave. $789 \pm 237 \mathrm{ng} \mathrm{kg}^{-1}$ ) in 2010 and from 36 to $1100 \mathrm{ng} \mathrm{kg}^{-1}$ (ave. $579 \pm 435 \mathrm{ng} \mathrm{kg}^{-1}$ ) in 2011 samples. The estimated lower limits of endotoxin in Tables 1 and 2 are calculated based on the minimum concentration of $\beta$ hydroxy FAs $\left(\mathrm{C}_{10}-\mathrm{C}_{18}\right)$, which are specific to Gram-negative bacteria (GNB). $\beta$-Hydroxy FAs $\left(\mathrm{C}_{10}-\mathrm{C}_{18}\right)$ are the structural constituents of lipid A, which are present in the outer cell membrane of GNB. Thus, the endotoxin concentrations in snow samples were estimated based on the abundances of $\beta$-hydroxy FAs having a carbon chain length from 10 to 18 (Sect. 2.3). Consistent with this study, Lee et al. (2004) also reported endotoxin concentrations based on $\beta$-hydroxy FAs $\left(\mathrm{C}_{10}-\mathrm{C}_{18}\right)$. Although relative abundances of endotoxin during the winter of $2010(N=5)$ are higher than those of 2011 samples $(N=6)$, the two-tailed $t$ test revealed no significant differences $(t=0.96 ; \mathrm{d} f=9 ; P>0.05)$ with regard to mean concentrations of the 2 years.

In this study, we estimated dry mass concentrations of GNB in snow samples to be $26.3 \pm 7.9 \mu \mathrm{g} \mathrm{kg}^{-1}$ in 2010 vs. $19.3 \pm 1.4 \mu \mathrm{g} \mathrm{kg}^{-1}$ in 2011 . Lee et al. (2007) reported that airborne endotoxin is of crustal origin and thus can be transported long distances to the outflow region. Since the AMBTs reveal the impact of long-range transport from Russia and Siberia during the study period, we infer that estimated endotoxin concentrations and dry cell weight of GNB over Sapporo are derived from those source regions. Recently, Golokhvast (2014) documented the airborne biogenic particles in snow from the Russian Far East that cause al-

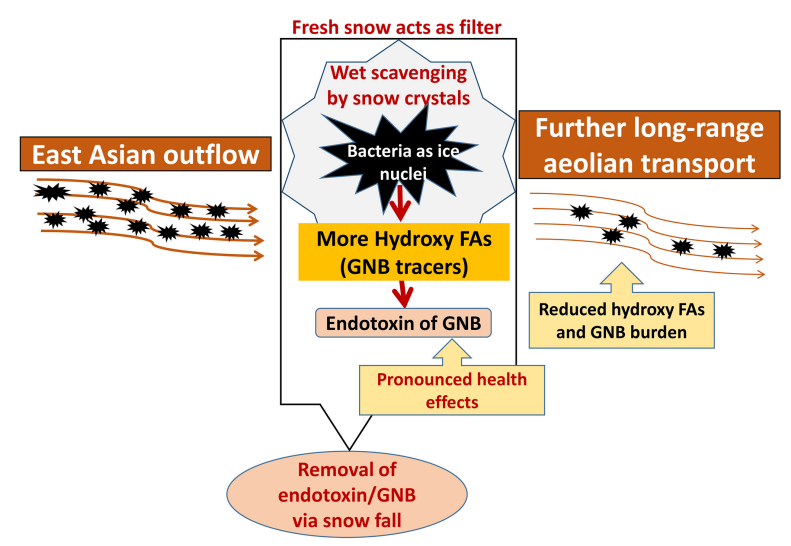

Figure 4. Conceptual model to explain the scavenging of hydroxy fatty acids (FAs) by fresh snow in the free troposphere. Snowfall in northern Japan acts as a filter in reducing the hydroxy FAs (tracers of Gram-negative bacteria; GNB), which in turn results in the removal of endotoxins from the atmosphere and a reduction in their health effects during long-range aeolian dust transport.

lergy for the pedestrians. The airborne biogenic particles can be scavenged efficiently by both wet precipitation and snowfall. Therefore, we have looked for the literature describing the occurrence of GNB in rainwater for comparison with our study on Sapporo snow. Towards this, Gould (1999) and Lye (2002) have documented the presence of various GNB (e.g., Salmonella, Shigella, Vibrio, Legionella and Campylobacter spp.) species in rainwater. Likewise, Kawamura and Kaplan (1983) also reported the presence of $\beta$-hydroxy FAs in rainwater samples collected from Los Angeles (USA) and attributed their sources to bacterial membranes. So far, no literature has been available on endotoxin and GNB concentrations in snow samples from East Asia in order to make a comprehensive comparison with the present study.

Overall, the presence of endotoxin and GNB in snow affirms that biogenic particles of soil microbes and their potential health impact should not be overlooked. Routine and long-term measurements of airborne chemical markers (hydroxy FAs in this study) could aid the monitoring of the microbial content in long-range transported air masses. Further studies are required to examine their distributions in the atmospheric environment and health effects on human beings in the regional and global perspectives during long-range atmospheric transport.

\section{Conclusions}

Although low temperature is considered to be a limiting factor for bacterial activity in air/snow, some studies have shown that bacteria can be metabolically active even at subzero temperatures (Polymenakou, 2012, and references therein). Figure 4 summarizes the whole idea, which was addressed in this study. We conclude that fresh snow in Japan acts as a fil- 
ter, which aids in reducing the burden of pathogenic microbes from the atmosphere via wet scavenging of these particles.

Owing to prolonged winters and, thus, snowfall in Sapporo, it is likely that ambient bacterial endotoxins (LPS) are largely scavenged from the atmosphere by snow, which can decrease their effect on human health via inhalation (Jacobs, 1989; Milton, 1996). However, without snow scavenging, ambient bacterial endotoxin levels may stay high and can be transported further long distances, which can cause severe impacts on human health over the North Pacific and possibly in North America. Overall, bacteria and their debris (biomass) can be evaluated in aerosols that are scavenged by snow in the free troposphere without prior culture by the determination of hydroxy FAs for both LPS and GNB.

\section{The Supplement related to this article is available online at doi:10.5194/bg-12-7071-2015-supplement.}

Author contributions. S. Yamamoto extracted the samples and conducted the experiments. P. Tyagi prepared the manuscript with contribution from K. Kawamura.

Acknowledgements. We appreciate the financial support from the Japanese Society for the Promotion of Science through grant-in-aid nos. 19204055 and 24221001. P. Tyagi is thankful to the Japanese Ministry of Education, Science and Culture (MEXT) for the Monbukagakusho scholarship.

Edited by: J. Middelburg

\section{References}

Aggarwal, S. G. and Kawamura, K.: Molecular distributions and stable carbon isotopic compositions of dicarboxylic acids and related compounds in aerosols from Sapporo, Japan: Implications for photochemical aging during long-range atmospheric transport, J. Geophys. Res.-Atmos., 113, D14301, doi:10.1029/2007JD009365, 2008.

Andersson, A., Weiss, N., Rainey, F., and Salkinoja-Salonen, M.: Dust-borne bacteria in animal sheds, schools and children's day care centres, J. Appl. Microbiol., 86, 622-634, 1999.

Balkwill, D. L., Leach, F. R., Wilson, J. T., McNabb, J. F., and White, D. C.: Equivalence of microbial biomass measures based on membrane lipid and cell wall components, adenosine triphosphate, and direct counts in subsurface aquifer sediments, Microb. Ecol., 16, 73-84, 1988.

Blokker, P., Schouten, S., de Leeuw, J. W., Damsté, J. S. S., and van den Ende, H.: Molecular structure of the resistant biopolymer in zygospore cell walls of Chlamydomonas monoica, Planta, 207, 539-543, 1999
Cardoso, J. N. and Eglinton, G.: The use of hydroxyacids as geochemical indicators, Geochim. Cosmochim. Ac., 47, 723-730, 1983.

Conte, M. H. and Weber, J.: Long-range atmospheric transport of terrestrial biomarkers to the western North Atlantic, Global Biogeochem. Cy., 16, 1142, doi:10.1029/2002GB001922, 2002.

Cranwell, P.: The stereochemistry of 2-and 3-hydroxy fatty acids in a recent lacustrine sediment, Geochim. Cosmochim. Ac., 45, 547-552, 1981.

Draxler, R. and Rolph, G.: HYSPLIT (HYbrid Single-Particle Lagrangian Integrated Trajectory), NOAA Air Resources Laboratory, College Park, MD, Model access via NOAA ARL READY Website, available at: http://ready.arl.noaa.gov/HYSPLIT.php (last access: 21 May 2015), 2013.

Eglinton, G., Hunneman, D., and Douraghi-Zadeh, K.: Gas chromatographic-mass spectrometric studies of long chain hydroxy acids - II: The hydroxy acids and fatty acids of a 5000year-old lacustrine sediment, Tetrahedron, 24, 5929-5941, 1968.

Feng, X., Gustafsson, Ö., Holmes, R. M., Vonk, J. E., van Dongen, B. E., Semiletov, I. P., Dudarev, O. V., Yunker, M. B., Macdonald, R. W., Montluçon, D. B., and Eglinton, T. I.: Multi-molecular tracers of terrestrial carbon transfer across the pan-Arctic: comparison of hydrolyzable components with plant wax lipids and lignin phenols, Biogeosciences, 12, 4841-4860, doi:10.5194/bg12-4841-2015, 2015.

Gagosian, R. B., Peltzer, E. T., and Zafiriou, O. C.: Atmospheric transport of continentally derived lipids to the tropical North Pacific, Nature, 291, 312-314, 1981.

Gagosian, R. B., Peltzer, E. T., and Merrill, J. T.: Long-range transport of terrestrially derived lipids in aerosols from the South $\mathrm{Pa}$ cific, Nature, 325, 800-803, doi:10.1038/325800a0, 1987.

Golokhvast, K. S.: Airborne biogenic particles in the snow of the cities of the russian far east as potential allergic compounds, J. Immunol. Res., 2014, 141378, doi:10.1155/2014/141378, 2014.

Goossens, H., Rijpstra, I. W. C., Düren, R., De Leeuw, J., and Schenck, P.: Bacterial contribution to sedimentary organic matter; a comparative study of lipid moieties in bacteria and recent sediments, Org. Geochem., 10, 683-696, 1986.

Gould, J. E.: Is rainwater safe to drink? A review of recent findings, in: Proceedings of the Ninth International Rainwater Catchment Systems Conference (IRCSA), Warwick's School of Engineering, Petrolina, Brazil, 6-9 July 1999.

Hines, C. J., Milton, D. K., Larsson, L., Petersen, M. R., Fisk, W. J., and Mendell, M. J.: Characterization and Variability of Endotoxin and 3-Hydroxy Fatty Acids in an Office Building During a Particle Intervention Study, Indoor Air, 10, 2-12, 2000.

Hines, C. J., Waters, M., Larsson, L., Petersen, M., Saraf, A., and Milton, D.: Characterization of endotoxin and 3-hydroxy fatty acid levels in air and settled dust from commercial aircraft cabins, Indoor Air, 13, 166-173, 2003.

Jacobs, R. R.: Airborne endotoxins: an association with occupational lung disease, Applied Industrial Hygiene, 4, 50-56, 1989.

Kawamura, K.: Land-derived lipid class compounds in the deep-sea sediments and marine aerosols from North Pacific, Biogeochemical Processes and Ocean Flux in the Western Pacific, Terra Scientific Publishing Company (TERRAPUB), Tokyo, 31-51, 1995.

Kawamura, K. and Gagosian, R.: Atmospheric transport of soilderived dicarboxylic acids over the North Pacific Ocean, Naturwissenschaften, 77, 25-27, 1990. 
Kawamura, K. and Ishiwatari, R.: Fatty acid geochemistry of a $200 \mathrm{~m}$ sediment core from Lake Biwa, Japan. Early diagenesis and paleoenvironmental information, Geochim. Cosmochim. Ac., 48, 251-266, 1984.

Kawamura, K. and Kaplan, I. R.: Organic compounds in the rainwater of Los Angeles, Environ. Sci. Technol., 17, 497-501, 1983.

Kawamura, K. and Kaplan, I.: Biogenic and anthropogenic organic compounds in rain and snow samples collected in southern California, Atmos. Environ., 20, 115-124, 1986.

Kawamura, K., Ishiwatari, R., and Ogura, K.: Early diagenesis of organic matter in the water column and sediments: microbial degradation and resynthesis of lipids in Lake Haruna, Org. Geochem., 11, 251-264, 1987.

Kawamura, K., Ishimura, Y., and Yamazaki, K.: Four years' observations of terrestrial lipid class compounds in marine aerosols from the western North Pacific, Global Biogeochem. Cy., 17, 1003-1022, doi:10.1029/2001GB001810, 2003.

Keinänen, M., Korhonen, L., Martikainen, P., Vartiainen, T., Miettinen, I., Lehtola, M., Nenonen, K., Pajunen, H., and Kontro, M.: Gas chromatographic-mass spectrometric detection of 2-and 3-hydroxy fatty acids as methyl esters from soil, sediment and biofilm, J. Chromatogr. B, 783, 443-451, 2003.

Larsson, L.: Determination of microbial chemical markers by gas chromatography-mass spectrometry-potential for diagnosis and studies on metabolism in situ, Apmis, 102, 161-169, 1994.

Lee, A. K. Y., Chan, C. K., Fang, M., and Lau, A. P. S.: The 3hydroxy fatty acids as biomarkers for quantification and characterization of endotoxins and Gram-negative bacteria in atmospheric aerosols in Hong Kong, Atmos. Environ., 38, 6307-6317, 2004.

Lee, A. K. Y., Lau, A. P., Cheng, J. Y., Fang, M., and Chan, C. K.: Source identification analysis for the airborne bacteria and fungi using a biomarker approach, Atmos. Environ., 41, 2831-2843, 2007.

Lehninger, A. L.: Biochemistry: the molecular basis of cell structure and functions, Worth, New York, 659, 1975.

Lüderitz, O., Galanos, C., and Rietschel, E. T.: Endotoxins of gramnegative bacteria, Pharmacol. Therapeut., 15, 383-402, 1981.

Lye, D. J.: Health risks associated with consumption of untreated water from household roof catchment systems, Journal of American Water Resource Association, 38, 1301-1306, 2002.

Matsumoto, G. I. and Nagashima, H.: Occurrence of 3-hydroxy acids in microalgae and cyanobacteria and their geochemical significance, Geochim. Cosmochim. Ac., 48, 1683-1687, 1984.

Mielniczuk, Z., Mielniczuk, E., and Larsson, L.: Gas chromatography-mass spectrometry methods for analysis of 2- and 3-hydroxylated fatty acids: Application for endotoxin measurement, J. Microbiol. Meth., 17, 91-102, 1993.

Milton, D. K.: Bacterial endotoxins: a review of health effects and potential impact in the indoor environment, in: Indoor Air and Human Health, edited by: Gammage, R. B. and Berven, B. A., Lewis Publishers, CRC Press, Florida, 2nd Edn., 179-195, 1996.

Molina, I., Bonaventure, G., Ohlrogge, J., and Pollard, M.: The lipid polyester composition of Arabidopsis thaliana and Brassica napus seeds, Phytochemistry, 67, 2597-2610, 2006.

Morris, C. E., Sands, D. C., Bardin, M., Jaenicke, R., Vogel, B., Leyronas, C., Ariya, P. A., and Psenner, R.: Microbiology and atmospheric processes: research challenges concerning the im- pact of airborne micro-organisms on the atmosphere and climate, Biogeosciences, 8, 17-25, doi:10.5194/bg-8-17-2011, 2011.

Pavuluri, C. M., Kawamura, K., Uchida, M., Kondo, M., and Fu, P.: Enhanced modern carbon and biogenic organic tracers in Northeast Asian aerosols during spring/summer, J. Geophys. Res.Atmos., 118, 2362-2371, 2013.

Polymenakou, P. N.: Atmosphere: a source of pathogenic or beneficial microbes?, Atmosphere, 3, 87-102, 2012.

Ratledge, C. and Wilkinson, S.: Fatty acids, related and derived lipids, Microbial lipids, 1, 23-52, 1988.

Rietschel, E. T., Wollenweber, H. W., Brade, H., Zähringer, U., Lindner, B., Seydel, U., Bradaczek, H., Barnickel, G., Labischinski, H., and Giesbrecht, P. (Eds.): Structure and conformation of lipid A component of lipopolysaccharides, Elsevier Science, Amsterdam, 187-220, 1984.

Sankelo, P., Kawamura, K., Seki, O., Shibata, H., and Bendle, J.: $\mathrm{n}$-Alkanes in fresh snow in Hokkaido, Japan: implications for ice core studies, Arct. Antarct. Alp. Res., 45, 119-131, 2013.

Saraf, A., Larsson, L., Burge, H., and Milton, D.: Quantification of ergosterol and 3-hydroxy fatty acids in settled house dust by gas chromatography-mass spectrometry: comparison with fungal culture and determination of endotoxin by a Limulus amebocyte lysate assay, Applied and Environ. Microbiol., 63, 2554-2559, 1997.

Satsumabayashi, H., Nishizawa, H., Yokouchi, Y., and Ueda, H.: Pinonaldehyde and some other organics in rain and snow in central Japan, Chemosphere, 45, 887-891, 2001.

Simoneit, B. R.: Biogenic lipids in particulates from the lower atmosphere over the eastern Atlantic, Nature, 267, 682-685, 1977.

Simoneit, B. R., Kobayashi, M., Mochida, M., Kawamura, K., Lee, M., Lim, H. J., Turpin, B. J., and Komazaki, Y.: Composition and major sources of organic compounds of aerosol particulate matter sampled during the ACE-Asia campaign, J. Geophys. Res.Atmos., 109, 1-22, doi:10.1029/2004JD004598, 2004.

Spaan, S., Smit, L., Eduard, W., Larsson, L., Arts, H., Wouters, I. M., and Heederik, D.: Endotoxin exposure in sewage treatment workers: investigation of exposure variability and comparison of analytical techniques, Ann. Agric. Environ. Med., 15, 251-261, 2008.

Steinberger, Y., Zelles, L., Bai, Q. Y., von Lützow, M., and Munch, J. C.: Phospholipid fatty acid profiles as indicators for the microbial community structure in soils along a climatic transect in the Judean Desert, Biol. Fert. Soils, 28, 292-300, 1999.

Stodola, F. H., Deinema, M. H., and Spencer, J.: Extracellular lipids of yeasts, Bacteriol. Rev., 31, 194-213, 1967.

Szponar, B., Norin, E., Midtvedt, T., and Larsson, L.: Limitations in the use of 3-hydroxy fatty acid analysis to determine endotoxin in mammalian samples, Journal of Microbiological Methods, 50, 283-289, 2002.

Tyagi, P., Ishimura, Y., and Kawamura, K.: Hydroxy fatty acids in marine aerosols as microbial tracers: 4-year study on $\beta$-and $\omega$ hydroxy fatty acids from remote Chichijima Island in the western North Pacific, Atmos. Environ., 115, 89-100, 2015.

Van Dyk, M., Kock, J., and Botha, A.: Hydroxy long-chain fatty acids in fungi, World J. Microb. Biot., 10, 495-504, 1994.

Volkman, J., Johns, R., Gillan, F., Perry, G., and Bavor, H.: Microbial lipids of an intertidal sediment - I. Fatty acids and hydrocarbons, Geochim. Cosmochimi. Ac., 44, 1133-1143, 1980. 
Wakeham, S. G.: Monocarboxylic, dicarboxylic and hydroxy acids released by sequential treatments of suspended particles and sediments of the Black Sea, Org. Geochem., 30, 1059-1074, 1999.

Wakeham, S. G., Pease, T. K., and Benner, R.: Hydroxy fatty acids in marine dissolved organic matter as indicators of bacterial membrane material, Org. Geochem., 34, 857-868, 2003.

Walters, M., Milton, D., Larsson, L., and Ford, T.: Airborne environmental endotoxin: a cross-validation of sampling and analysis techniques, Appl. Environ. Microb., 60, 996-1005, 1994.

Westphal, O.: Bacterial endotoxins (part 1 of 2), Int. Arch. Allergy. Imm., 49, 1-21, 1975.

Wilkinson, S. G.: Gram-negative bacteria, in: Microbial Lipids, edited by: Ratledge, C. and Wilkinson, S. G., Vol. 1., Academic Press, New York, 299-488, 1988.
Yamamoto, S., Kawamura, K., and Seki, O.: Long-range atmospheric transport of terrestrial biomarkers by the Asian winter monsoon: Evidence from fresh snow from Sapporo, northern Japan, Atmos. Environ., 45, 3553-3560, 2011.

Zelles, L.: Phospholipid fatty acid profiles in selected members of soil microbial communities, Chemosphere, 35, 275-294, 1997.

Zelles, L. and Bai, Q. Y.: Fatty acid patterns of phospholipids and lipopolysaccharids in environmental samples, Chemosphere, 28, 391-411, 1994.

Zhang, Z., Metzger, P., and Sachs, J. P.: Bound lipid biomarkers in sediments from El Junco Lake, Galápagos Islands, Org. Geochem., 75, 122-128, 2014. 